\title{
miR-199a-3p suppresses cervical epithelial cell inflammation by inhibiting the HMGB1/TLR4/NF-кB pathway in preterm birth
}

\author{
JUAN PENG $^{1-3^{*}}$, JIANG JIANG $^{1,2^{*}}$, HUIZI WANG ${ }^{1,2}$, XINZI FENG ${ }^{1,2}$ and XUDONG DONG ${ }^{1-3}$ \\ ${ }^{1}$ Department of Obstetrics, The Affiliated Hospital of Kunming University of Science and Technology; \\ ${ }^{2}$ Department of Obstetrics, The First People's Hospital of Yunnan Province; ${ }^{3}$ Medicine Faculty of \\ Kunming University of Science and Technology, Kunming, Yunnan 650031, P.R. China
}

Received September 3, 2019; Accepted April 9, 2020

DOI: $10.3892 / \mathrm{mmr} .2020 .11184$

\begin{abstract}
Preterm birth (PTB) is the primary cause of neonatal mortality worldwide. Infection and inflammation are considered to be the primary causes of PTB. Cervical remodeling is an important step in the process of preterm delivery, and the destruction of the cervical epithelial barrier and inflammation are important triggers of cervical remodeling. The aim of the present study was to determine the effect and underlying mechanism of microRNA (miR)-199a-3p/high-mobility group box 1 protein (HMGB1) signaling in cervical epithelial inflammation in PTB. The results of this study revealed that miR-199a-3p was significantly decreased in cervical epithelial tissue samples from patients in both the preterm labor and preterm premature rupture of membrane groups. This decrease was also observed in tissue samples from a lipopolysaccharide (LPS)-induced PTB mouse model and in LPS-induced ectocervical and endocervical cells. Whereas, the expression of HMGB1 and toll-like receptor 4 (TLR4) was significantly increased, which was associated with the upregulation of interleukin (IL)- $1 \beta$ and tumor necrosis factor (TNF)- $\alpha$ expression. Furthermore, overexpression of miR-199a-3p significantly suppressed the expression and activation of HMGB1 and TLR4/NF- $\kappa$ B signaling, and decreased the levels of IL-1 $\beta$ and TNF- $\alpha$ in vitro and in vivo. Additionally, overexpression of HMGB1 and/or TLR4 reversed the anti-inflammatory effects of miR-199a-3p mimics in vitro and in vivo. These results indicate that miR-199a-3p acts as a negative inflammatory regulator in PTB by targeting HMGB1 to regulate the TLR4/NF-kB pathway.
\end{abstract}

Correspondence to: Dr Xudong Dong, Department of Obstetrics, The Affiliated Hospital of Kunming University of Science and Technology, The First People's Hospital of Yunnan Province, 157 Jinbi Road, Xishan, Kunming, Yunnan 650031, P.R. China E-mail: dxdkhck@163.com

Key words: microRNA-199a-3p, preterm birth, cervical epithelial cells, high-mobility group box 1 protein, inflammation, toll-like receptor $4 / \mathrm{NF}-\kappa \mathrm{B}$ pathway

\section{Introduction}

Preterm birth (PTB) refers to delivery at $<37$ weeks of gestation, it is a global issue and a leading cause of infant morbidity and mortality worldwide (1). Spontaneous preterm labor is a syndrome involving a number of pathophysiological processes that is primarily caused by intra-amniotic infection/inflammation (2). Compared with the normal population, pregnant women have increased susceptibility to pathogens in the environment, thus increasing the risk of adverse pregnancy outcomes (3). Inflammation, or more specifically inflammatory activation caused by infection or other factors, plays key roles in uterine activation and delivery (4), including promoting inflammatory factor responses and destroying the cervical epithelial barrier, thus inducing cervical remodeling (5). Cervical remodeling is a natural, continually occurring process over the course of gestation, but the mechanism of its occurrence and progression remains largely unknown.

The production of inflammatory cytokines caused by inflammatory activation is closely related to the maintenance of uterine quiescence and the induction of uterine activation during pregnancy $(6,7)$. The increased production of proinflammatory cytokines is related to uterine activation and the occurrence of PTB, whereas anti-inflammatory cytokines play an essential role in uterine quiescence during gestation $(8,9)$. High-mobility group box 1 protein (HMGB1) is a member of the highly conserved non-histone DNA binding protein family, and a potent mediator of inflammation in multiple pathological processes, such as endotoxemia and sepsis induced by bacterial infection, gastrointestinal inflammation, pancreatitis, ischemia-reperfusion injury and transplantation, and intra-amniotic inflammation-determined preterm birth $(10,11)$. HMGB1 is secreted by innate immune cells in response to pathogens and is released by injured or dying cells, thus it plays a central role in the pathogenesis of both sterile and infectious inflammation (12). It has been reported that HMGB1 levels are significantly increased in PTB (11,13-15). Toll-like receptors (TLRs) are a family of evolutionarily conserved innate immune receptors that act as sensors of invading pathogens and link innate and acquired immunity $(11,16)$. HMGB1 is a ligand that promotes TLR4 activity. TLR4 is the primary receptor of endogenous extracellular HMGB1, which can activate NF- $\kappa \mathrm{B}$ and mediate its nuclear translocation, thus 
upregulating the expression of cytokines and other inflammatory mediators (17-20). A previous study has revealed that the TLR4/NF-KB signaling pathway is involved in advancing gestational age, exposure to chorioamnionitis and preterm premature rupture of membranes (PPROM) (21). However, the regulatory mechanism of $\mathrm{HMGB} 1$ and TLR4/NF- $\mathrm{KB}$ signaling in inflammatory activation in PTB remains unknown.

MicroRNAs (miRNAs/miRs) are a class of small non-coding single-stranded RNAs that are 18-22 nucleotides in length. They negatively regulate gene expression via degradation or posttranscriptional regulation of target mRNAs. Numerous studies have suggested that miRNAs are involved in PTB (22-25). Previous studies have reported that miR-199a and miR-214 are significantly decreased in the laboring myometrium of pregnant mice and humans, and in an inflammatory mouse model of preterm labor (26), and they are important regulators of myometrial contractility. It has also been reported that miR-199a-3p plays a crucial role in regulating the process of inflammation in multiple diseases, including cystic fibrosis airways (27) and acute lung injury (28). However, it is unclear whether miR-199a-3p is involved in the regulation of uterine activation and quiescence by regulating inflammatory activation.

Based on previous studies, it was hypothesized that miR-199a-3p may play an important role in PTB-related inflammatory activation. Notably, it has been suggested that miR-199a-3p may regulate HMGB1 expression by targeting the HMGB1 mRNA 3'untranslated region (UTR) through a bioinformatic prediction (http://www.targetscan.org/vert_72/). The present study aimed to investigate the mechanism by which miR-199a-3p regulates the TLR4/NF- $\kappa$ B-mediated inflammatory response by targeting HMGB1 in preterm delivery. This study will provide more evidence related to the pathogenesis of inflammatory-related PTB and provide new insights into the targets and strategies for PTB prevention.

\section{Materials and methods}

Human tissue preparations. All human studies were approved by the Hospital Ethical Committee of The First People's Hospital of Yunnan Province and Affiliated Hospital of Kunming University of Science and Technology located in Kunming, China (approval no: 2016LH087), and written informed consent was obtained from each patient before surgery. A total of 182 females participated in this study, these patients had been admitted to The First People's Hospital of Yunnan Province between January and September 2019. The details and baseline characteristics of the participants are shown in Table S1. Of these 182 participants, 52 were in the PTB group, 60 were in the PPROM group and 70 were in the full-term birth (TB) group. The peripheral blood and cervical epithelial tissues were collected from participants within 30 min of delivery, immediately frozen and stored at $-80^{\circ} \mathrm{C}$ for subsequent study.

Cell culture and transfection. The ectocervical (Ecto) cell line Ect1/E6E7 (cat. no. CRL-2614) and endocervical (Endo) cell line End1/E6E7 (cat. no. CRL-2615) were purchased from American Type Culture Collection (ATCC) and cultured in keratinocyte serum medium (KSM; Gibco; Thermo Fisher Scientific, Inc.) supplemented with $0.1 \mathrm{ng} / \mathrm{ml}$ epidermal growth factor, $50 \mu \mathrm{g} / \mathrm{ml}$ bovine pituitary extract (ScienCell Research Laboratories, Inc.) and $0.1 \%$ penicillin-streptomycin solution at $37^{\circ} \mathrm{C}$ in a humidified incubator with $5 \% \mathrm{CO}_{2}$. 293T cells were purchased from ATCC and cultured in Dulbecco's modified Eagle's medium (DMEM; Gibco; Thermo Fisher Scientific, Inc.) supplemented with $10 \%$ fetal bovine serum (FBS, Gibco; Thermo Fisher Scientific, Inc.) and $0.1 \%$ penicillin-streptomycin solution at $37^{\circ} \mathrm{C}$ in a $5 \% \mathrm{CO}_{2}$ humidified incubator.

For the transfection experiment, Ecto and Endo cells were seeded into 6-well plates (Coning, Inc.) at $1.5 \times 10^{5}$ cells $/$ well for $24 \mathrm{~h}$. Then, cells were transfected with $100 \mathrm{nM}$ miR-199a-3p mimics (5'-ACAGUAGUC UGCACAUUGGUUA-3') and negative miRNA mimics (5'-UAA CCAAUGUGCAGACUACUGU-3') using Lipofectamine ${ }^{\circledR}$ 2000 (Invitrogen; Thermo Fisher Scientific, Inc.), according to the manufacturer's protocols. The transfection efficiency was verified by reverse transcription-quantitative (RT-q)PCR $4 \mathrm{~h}$ later. miR-199a-3p mimics and negative control mimics were obtained from Shanghai GenePharma Co., Ltd.

For HMGB1 and TLR4 overexpression experiments, $293 \mathrm{~T}$ cells were seeded into 24 -well plates (Coning, Inc.) at $1 \times 10^{5}$ cells/well for $24 \mathrm{~h}$. Clone vectors of HMGB1 and TLR4 were purchased from Shanghai GenePharma Co., Ltd. Subsequently, the linearized DNA, shuttle vector and pacAd vector were co-transfected into 293T cells using Lipofectamine 2000 (Invitrogen; Thermo Fisher Scientific, Inc.). Viral lysates were harvested and purified before infecting Ecto and Endo cells. One day before the experiment, Ecto and Endo cells were seeded into 6 -well plates (Coning, Inc.) at $1.5 \times 10^{5}$ cells/well. Then, $50 \mathrm{nM}$ adenoviruses were added to the medium to infect the Ecto and Endo cells, the transfection efficiency was verified by western blotting $24 \mathrm{~h}$ later.

LPS-induced inflammation in Ecto and Endo cells. Ecto and Endo cells were seeded into 24 -well plates at a concentration of $1 \times 10^{5}$ cells/well for $24 \mathrm{~h}$ in KSM supplemented with $0.1 \mathrm{ng} / \mathrm{ml}$ epidermal growth factor, $50 \mu \mathrm{g} / \mathrm{ml}$ bovine pituitary extract (ScienCell Research Laboratories, Inc.) and $0.1 \%$ penicillin-streptomycin solution at $37^{\circ} \mathrm{C}$ with $5 \% \mathrm{CO}_{2}$. Then, the medium was changed to keratinocyte serum-free medium supplemented with $0.1 \%$ penicillin-streptomycin solution for $24 \mathrm{~h}$. Then, the cells were treated with $25 \mu \mathrm{g} / \mathrm{ml}$ LPS (Sigma-Aldrich; Merck KGaA), and the control group was treated with an equivalent of saline. The cell culture supernatant was collected at 6 and $24 \mathrm{~h}$, and the cytokines were assayed at both time points using an enzyme-linked immunosorbent assay (ELISA) kit.

$R T-q P C R$. Total RNA was extracted from cervical tissues and cells using TRIzol reagent (Invitrogen; Thermo Fisher Scientific, Inc.) and then reverse transcribed using a PrimeScript RT regent kit (Takara Biotechnology Co., Ltd.), following the manufacturer's instructions (with the temperature protocol of $37^{\circ} \mathrm{C}$ for $15 \mathrm{~min}$, and $85^{\circ} \mathrm{C}$ for $5 \mathrm{sec}$ ). RT-qPCR was carried out using SYBR Real-Time PCR Master Mix (Takara Biotechnology Co., Ltd.) on an ABI 7500 Real-Time PCR System (Applied Biosystems; Thermo Fisher Scientific, Inc.). The thermocycling conditions were as follows: Initial denaturation at $95^{\circ} \mathrm{C}$ for $10 \mathrm{sec}$, followed by 40 cycles of $95^{\circ} \mathrm{C}$ for $10 \mathrm{sec}$ and $60^{\circ} \mathrm{C}$ for $30 \mathrm{sec}$. The mRNA level was normalized to GAPDH and miRNA level 
was normalized to U6. The relative levels were calculated by the $2^{-\Delta \Delta \mathrm{Cq}}$ method (29). The primer sequences used were as follows: Human GAPDH, forward: 5'-TTCCGTGTTCCTACCC-3' and reverse: 5'-GTCGCAGGAGACAACC-3'; human U6, forward: 5'-CTCGCTTCGGCAGCACATATACT-3' and reverse: 5'-ACGCTTCACGAATTTGCGTGTC-3'; human HMGB1, forward: 5'-CAAACCTGCCGGGAGCAGCA-3' and reverse: 5'-TCTTTCATAACGAGCCTTGTCAGCC-3'; human TLR4, forward: 5'-TATCCAGAGCCGTTGGTGTA-3' and reverse: 5'-CCCACTCGAGGTAGGTGTTT-3'; human interleukin (IL)-1 $\beta$, forward: 5'-TGAGCTCGCCAGTGAAATGA-3' and reverse: 5'-AACACGCAGGACAGGTACAG-3'; and human tumor necrosis factor (TNF)- $\alpha$, forward: 5'-CCAGACCCTCACACTCAGATCA-3' and reverse: 5'-CACTTGGTGGTTTGCTACGAC-3'. In addition, miRNA qPCR was carried out using a TaqMan ${ }^{\mathrm{TM}}$ Reverse Transcription kit (Applied Biosystems; Thermo Fisher Scientific, Inc.) and a TaqMan Universal PCR Master Mix (Applied Biosystems; Thermo Fisher Scientific, Inc.).

Luciferase reporter assays. The binding sites between miR-199a-3p and HMGB1 was predicted with TargetScan (http://www.targetscan.org/vert_72/). Luciferase vectors containing the 3'UTR of human HMGB1 with the miR-199a-3p binding sites and mutant miR-199a-3p binding sites, were purchased from Shanghai GenePharma Co., Ltd. A total of $1 \times 10^{4} 293 \mathrm{~T}$ cells were cultured for $24 \mathrm{~h}$ and then transfected with the plasmid (wt-luc-HMGB1 or mut-luc-HMGB1) by Lipofectamine $^{\mathrm{TM}} 2000$ Transfection Reagent (Invitrogen; Thermo Fisher Scientific, Inc.). The pRL-CMV vector containing the CMV enhancer and early promoter elements of Renilla luciferase (Promega Corporation) was used as an internal control. The luciferase activity was measured using the Dual-Luciferase ${ }^{\circledR}$ Reporter Assay System (Promega Corporation) $24 \mathrm{~h}$ post transfection.

Peripheral blood specimens. Peripheral blood specimens were collected, incubated for $15 \mathrm{~min}$ at room temperature and then centrifuged at $1,000 \mathrm{xg}$ at $4^{\circ} \mathrm{C}$ for $15 \mathrm{~min}$. The serum samples were stored at $-20^{\circ} \mathrm{C}$.

ELISA. The concentration of cytokines IL-1 $\beta$ (cat. no. DLB50), IL-6 (cat. no. D6050) and TNF- $\alpha$ (cat. no. DTA00D; all purchased from R\&D Systems, Inc.) in serum from participants were measured using ELISA kits following the manufacturer's instructions.

Western blotting. The Ecto and Endo cells were harvested and lysed in RIPA buffer with protease inhibitors (Invitrogen; Thermo Fisher Scientific, Inc.). Protein concentrations were determined using the Pierce BCA assay (Invitrogen; Thermo Fisher Scientific, Inc.), according to the manufacturer's protocols. $40 \mathrm{ng}$ of proteins were loaded on a $12.5 \%$ SDS-PAGE and subsequently transferred to PVDF membranes. The membranes were blocked with 5\% non-fat milk for $1 \mathrm{~h}$ at room temperature. Then, the cells were incubated with primary antibodies at $4^{\circ} \mathrm{C}$ overnight. Expression levels of the proteins of interest were analyzed using primary antibodies against inhibitor of $\mathrm{NF}-\kappa \mathrm{B}$

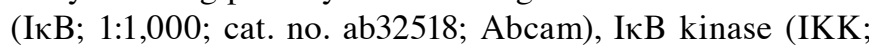
1:1,000; cat. no. ab32041; Abcam), HMGB1 (1:12,000; cat. no. ab79823; Abcam), TLR4 (1:100; cat. no. ab22048; Abcam), cAMP response element-binding protein (CREB; 1:500; cat. no. ab32515; Abcam), phosphorylated (p)-CREB (1:5,000; cat. no. ab32096; Abcam), p65 (1:1,000; cat. no. ab16502; Abcam) and p-p65 (1:16,000; cat. no. ab6503; Abcam). Membranes were rinsed three times with $1 \mathrm{X}$ Tris-buffered saline with $0.5 \%$ Tween-20 (TBST), and then incubated with anti-rabbit IgG (1:2,000; cat. no. ab205718; Abcam) horseradish peroxidase-conjugated secondary antibody for $1 \mathrm{~h}$ at room temperature. Membranes were rinsed three times with TBST and visualized using an ECL kit (Bio-Rad Laboratories, Inc.). The protein bands were quantified using ImageJ software (v1.52a; National Institutes of Health), and GAPDH was used as a loading control. Each experiment was performed in triplicate.

Mouse model of LPS-induced preterm labor. A total of 25 eight-week-old timed pregnant Institute of Cancer Research (ICR) mice (28-32 g) were obtained from Guangdong Medical Laboratory Animal Center. The mice were housed individually with a 12 -h light/dark cycle at $22^{\circ} \mathrm{C}$ with $50 \%$ humidity and received ad libitum food and water. All experiments were approved by the Animal Ethics Committee of the hospital. The LPS-induced preterm mouse model was described in a previous study (30). Briefly, pregnant ICR mice (15.5 days post conception) were anesthetized by intraperitoneal injection with $1 \%$ sodium pentobarbital $(50 \mathrm{mg} / \mathrm{kg})$ before performing laparotomy to expose the uterus. LPS (Sigma-Aldrich; Merck $\mathrm{KGaA}$ ) at a dose of $1.5 \mu \mathrm{g}$ in $50 \mu \mathrm{l}$ or an equal volume of sterile PBS was injected into each amniotic sac. The uterus was then carefully reinserted into the abdominal cavity, the abdominal muscle wall and skin were sutured, and the mouse was allowed to recuperate. The LPS-induced mice $(n=5)$ were sacrificed upon the PTB of one pup, and the control mice $(n=5)$ were sacrificed immediately afterwards. Then, to determine the miR-199a-3p and HMGB1 in cervical epithelial inflammation in vivo, miR-199a-3p mimics and pcDNA-HMGB1 were transfected into LPS-induced PTB mice together or alone [the mice were divided into 3 groups: LPS only $(n=5)$; miR-199a-3p mimics only $(n=5)$; and miR-199a-3p mimics and pcDNA-HMGB1 $(n=5)]$, and the transfection efficiency was verified by RT-qPCR or western blotting. Subsequently, the expression of HMGB1, TLR4, p65, p-p65 and the proinflammatory cytokines, IL-1 $\beta$ and TNF- $\alpha$, were measured.

Statistical analysis. All data are presented as the mean \pm SEM. Differences between two or multiple groups were evaluated using a two-tailed Student's t-test or one-way ANOVA followed by Bonferroni post hoc test. The baseline characteristics of participants were tested by Kruskal-Wallis test and Fisher's Exact test. Statistical analyses were performed using SPSS v20.0 (IBM Corp.) and GraphPad Prism 7.0 software (GraphPad Software, Inc.). $\mathrm{P}<0.05$ was considered to indicate a statistically significant difference.

\section{Results}

Expression of miR-199a-3p and HMGB1 in the PTB group. A total of 182 females participated in the present study, which included 52 patients in the PTB group, 60 in the PPROM group and 70 in the TB group. mRNA expression of miR-199a-3p 
A

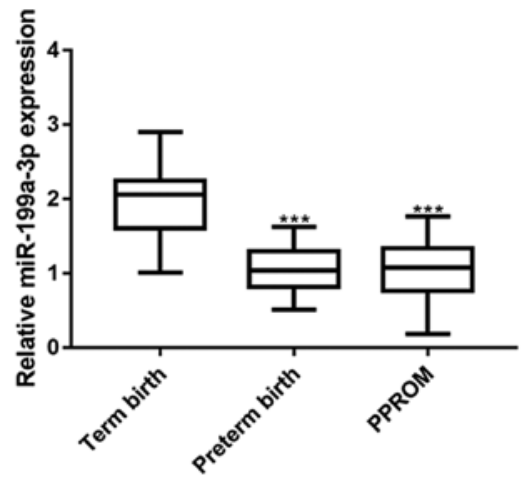

C

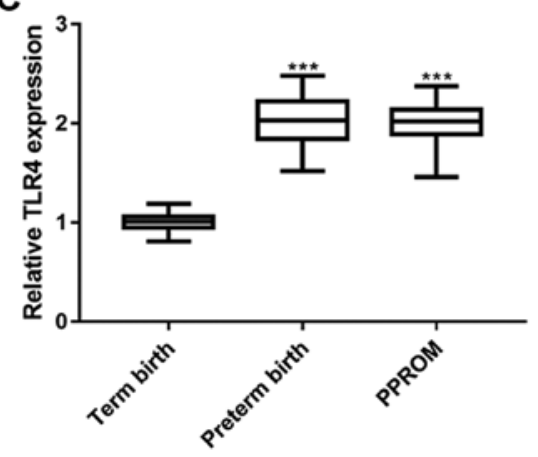

B

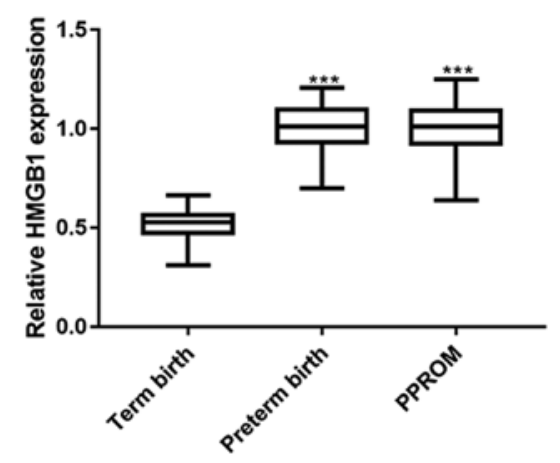

D

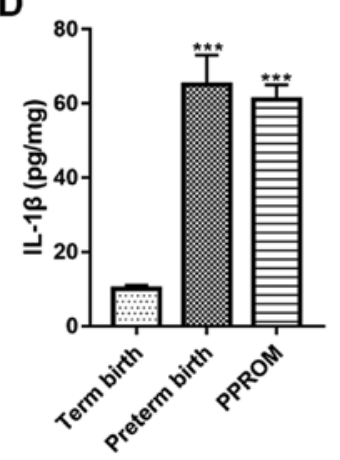

E

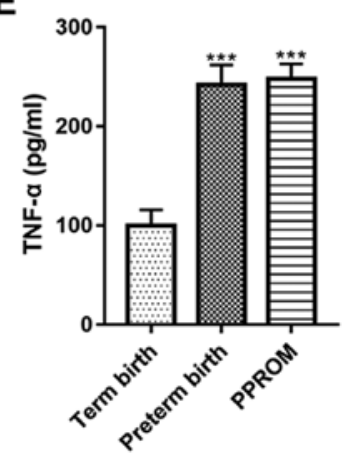

Figure 1. Expression of miR-199a-3p and HMGB1 in cervical tissue samples from patients. The expression of (A) miR-199a-3p, (B) HMGB1 mRNA and (C) TLR4 mRNA in cervical tissue samples from patients in the term birth, preterm birth and PPROM groups measured by reverse transcription-quantitative PCR. The serum levels of (D) IL-1 $\beta$ and (E) TNF- $\alpha$ in cervical tissue samples from patients in the term birth, preterm birth and PPROM groups, measured using an ELISA assay. Data represents the mean \pm SEM. ${ }^{* * * *} \mathrm{P}<0.001$ vs. term birth. miR, microRNA; HMGB1, high-mobility group box 1 protein; TLR4, toll-like receptor 4; PPROM, preterm premature rupture of membranes; IL, interleukin; TNF, tumor necrosis factor.

\section{A}

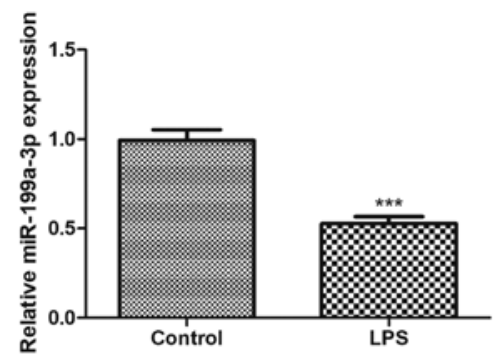

C

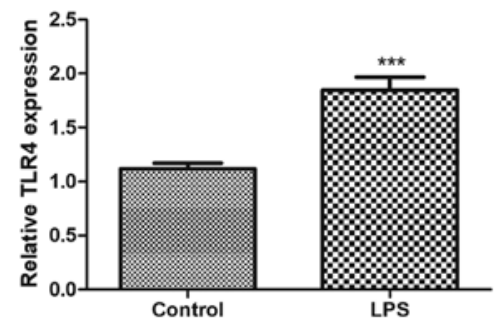

$\mathrm{E}$

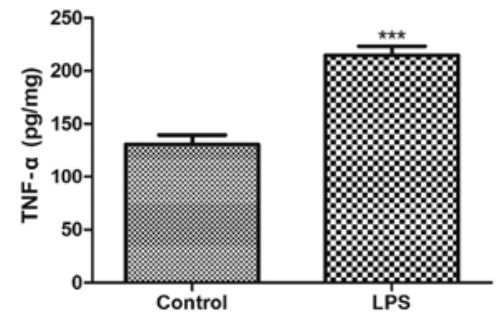

B

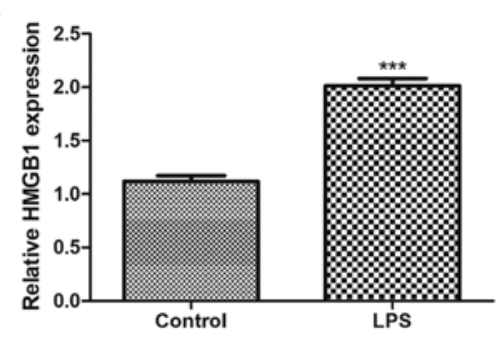

D

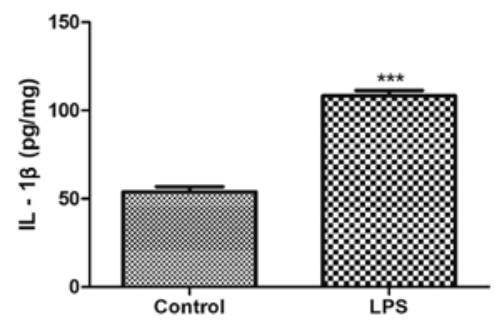

Figure 2. Expression of miR-199a-3p and HMGB1 in LPS-induced preterm mouse model. LPS (1.5 $\mu \mathrm{g}$ in $50 \mu \mathrm{l})$ was used to induce preterm birth in mice. The expression of (A) miR-199a-3p, (B) HMGB1 mRNA and (C) TLR4 mRNA in cervical samples from preterm mice compared with control mice, as determined by reverse transcription-quantitative PCR. The serum levels of (D) IL-1 $\beta$ and (E) TNF- $\alpha$ in preterm mice compared with control mice, as measured by an ELISA assay. Data represents the mean \pm SEM. ${ }^{* * *} \mathrm{P}<0.001$ vs. control. miR, microRNA; HMGB1, high-mobility group box 1 protein; TLR4, toll-like receptor 4; IL, interleukin; TNF, tumor necrosis factor; LPS, lipopolysaccharide. 
A

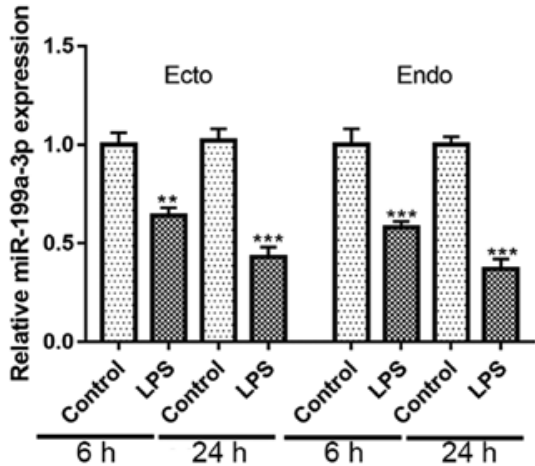

C

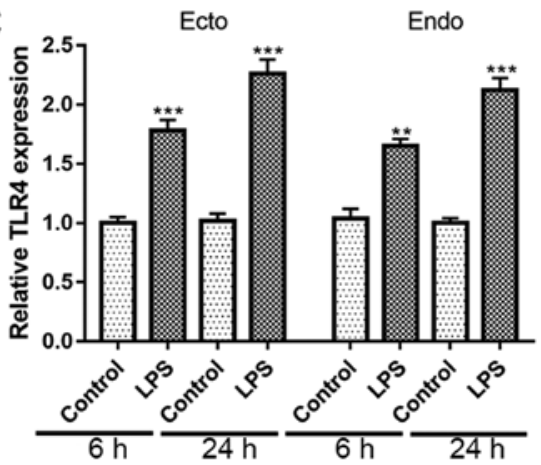

E

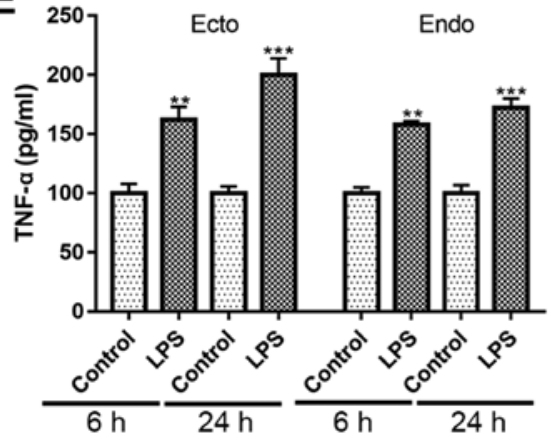

B

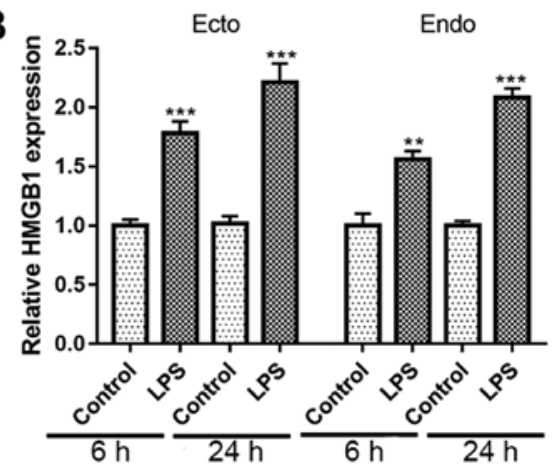

D

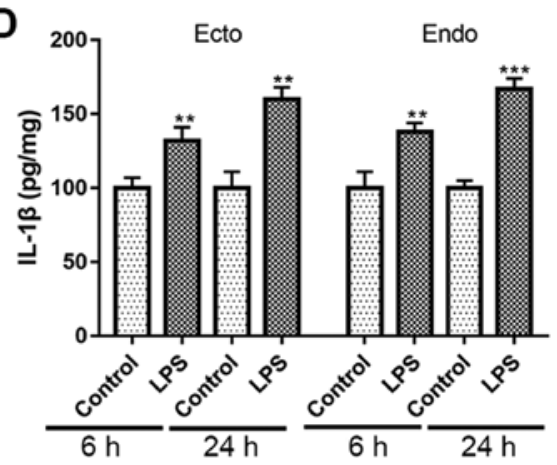

Figure 3. Expression of miR-199a-3p and HMGB1 in LPS-induced cervical epithelial cells. The expression of (A) miR-199a-3p, (B) HMGB1 mRNA and (C) TLR4 mRNA in Ecto and Endo cells at 6 and $24 \mathrm{~h}$ after LPS $(25 \mu \mathrm{g} / \mathrm{ml})$ treatment, as determined by reverse transcription-quantitative PCR. The levels of (D) IL-1 $\beta$ and (E) TNF- $\alpha$ in the cell culture medium of Ecto and Endo cells at 6 and $24 \mathrm{~h}$ after LPS $(25 \mu \mathrm{g} / \mathrm{ml})$ treatment, as detected using an ELISA assay Data represents the mean $\pm \mathrm{SEM} .{ }^{* *} \mathrm{P}<0.01,{ }^{* * *} \mathrm{P}<0.001$ vs. control. miR, microRNA; HMGB1, high-mobility group box 1 protein; TLR4, toll-like receptor 4; IL, interleukin; TNF, tumor necrosis factor; LPS, lipopolysaccharide; Ecto, ectocervical; Endo, endocervical.

and HMGB1 in the cervical tissues of patients in the PTB, PPROM and TB groups were determined by RT-qPCR. The results showed that the expression of miR-199a-3p was significantly decreased in the cervical tissue of patients in the PTB and PPROM groups compared with patients in the TB group (Fig. 1A). In contrast, the mRNA levels of HMGB1 and TLR4 were significantly increased in patients in the PTB and PPROM groups compared with in the TB group (Fig. 1B and C). Furthermore, serum levels of proinflammatory cytokines (IL-1 $\beta$ and TNF- $\alpha$ ) were significantly increased in the PTB and PPROM groups compared with in the TB group (Fig. 1D and E). In addition, there were no significant differences between the PTB and PPROM groups. These results suggested that there is a significant inflammatory response in PTB and PPROM conditions, which may be related to the abnormal expression of miR-129-3p, HMGB1 and TLR4.
Expression of miR-199a-3p and HMGB1 in an LPS-induced preterm mouse model. The expression levels of miR-199a-3p, HMGB1 and TLR4 in cervical tissue from PTB mice and the level of inflammation in PTB mice were found to be similar to those observed in patients in the PTB group. As shown in Fig. 2, the LPS-induced preterm mouse model resulted in significant downregulation of miR-199a-3p and upregulation of the mRNA expression levels of HMGB1 and TLR4 compared with those in control mice (Fig. 2A-C). Furthermore, serum IL- $1 \beta$ and TNF- $\alpha$ showed significant increases in LPS-induced PTB mice (Fig. 2D and E). These results indicated that LPS-induced inflammatory preterm delivery in pregnant mice might be achieved by regulating the expression of miR-199a-3p, HMGB1 and TLR4.

Expression of miR-199a-3p and HMGB1 in LPS-induced cervical epithelial cells. Ecto and Endo cells were exposed 

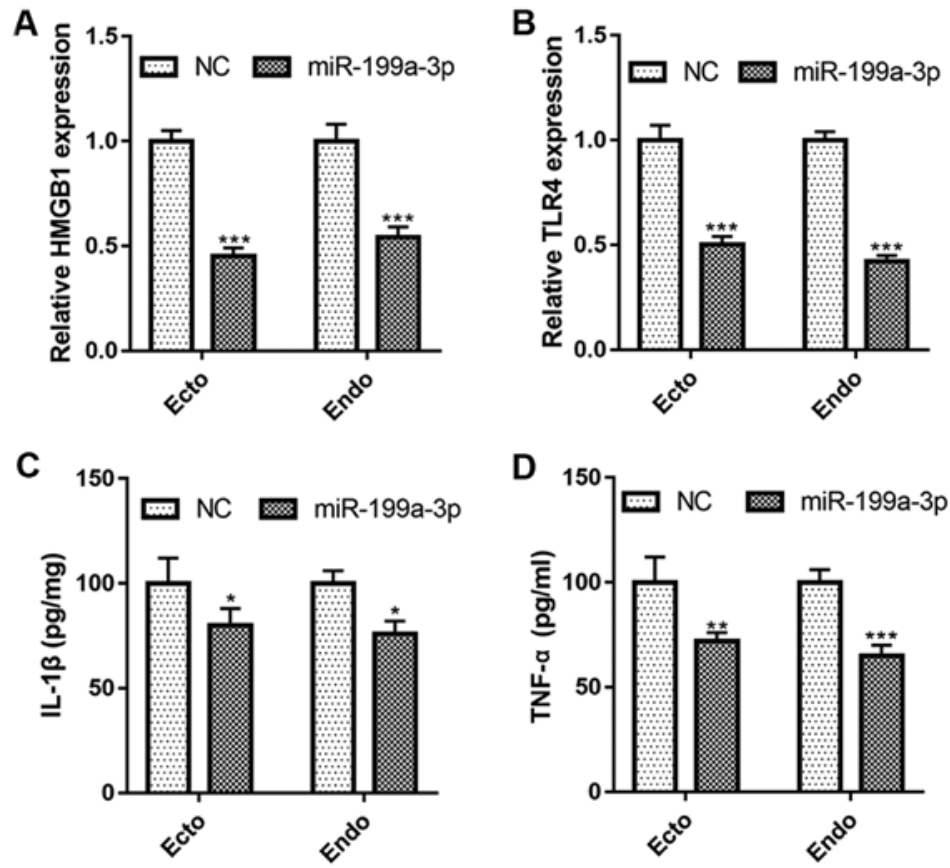

Figure 4. Overexpression of miR-199a-3p inhibits inflammatory phenotype in vitro. The mRNA expression of (A) HMGB1 and (B) TLR4 in Ecto and Endo cells after miR-199a-3p overexpression, as determined by reverse transcription-quantitative PCR. The levels of (C) IL-1 $\beta$ and (D) TNF- $\alpha$ in the cell culture medium of Ecto and Endo cells after miR-199a-3p overexpression, as measured by ELISA assay. Data represents the mean $\pm \mathrm{SEM}$. $\mathrm{P}<0.05,{ }^{* *} \mathrm{P}<0.01$, ${ }^{* * *} \mathrm{P}<0.001$ vs. NC. miR, microRNA; HMGB1, high-mobility group box 1 protein; TLR4, toll-like receptor 4; IL, interleukin; TNF, tumor necrosis factor; LPS, lipopolysaccharide; Ecto, ectocervical; Endo, endocervical; NC, negative control.

to LPS, and the expression of genes was measured at 6 and $24 \mathrm{~h}$ after exposure in both cell lines. The results showed that the expression of miR-199a-3p significantly decreased in both cell lines in a time-dependent manner (Fig. 3A). Similar to patients in the PTB group and LPS-induced preterm mice, the mRNA expression of HMGB1 and TLR4 were significantly increased in Ecto and Endo cells in a time-dependent manner (Fig. 3B and C). In addition, the L-1 $\beta$ and TNF- $\alpha$ levels were also significantly increased in Ecto and Endo cells in a time--dependent manner (Fig. 3D and E). These data suggested that miR-199a-3p and HMGB1 play important roles in LPS-induced inflammation of cervical epithelial cells in vitro.

Overexpression of $\mathrm{miR}-199 \mathrm{a}-3 \mathrm{p}$ inhibits the inflammatory phenotype in vitro. To investigate the effect of miR-199a-3p on cervical epithelial cell inflammation, Ecto and Endo cells were transfected with miR-199a-3p mimics (transfection efficiency presented in Fig. S1A), which significantly decreased the mRNA expression of HMGB1 and TLR4 (Fig. 4A and B). Concurrently, transfection of miR-129-3p mimics inhibited the proinflammatory cytokine production in both Ecto and Endo cells. As shown in Fig. 4C and D, the levels of IL-1 $\beta$ and TNF- $\alpha$ were significantly decreased after miR-129-3p overexpression. These results suggested that upregulation of the expression of miR-199a-3p could inhibit the expression of HMGB1 and TLR4, and contribute to anti-inflammation in cervical epithelial cells in vitro.

Overexpression of miR-199a-3p suppresses the $N F-\kappa B$ pathway in cervical epithelial cells. To explore whether miR-199a-3p influences inflammatory responses by regulating the NF- $\kappa$ B pathway, Ecto and Endo cells were transfected with miR-199a-3p mimics, and the proteins involved in the NF- $\kappa \mathrm{B}$ pathway were detected by western blotting. As shown in Fig. 5, there was a significant increase in the protein expression of $\mathrm{I} \kappa \mathrm{B}$ and activated p-CREB (Fig. 5A, B and D). In contrast, the protein expression levels of IKK and p-p65 were significantly decreased (Fig. 5A, C and E). Notably, the expression of total CREB and p65 showed no obvious change (Fig. 5A). These data demonstrated that overexpression of miR-129-3p could inhibit the activation of $\mathrm{NF}-\kappa \mathrm{B}$ signaling, which indicated that the $N F-\kappa B$ pathway participates in the regulation of the inflammatory response by miR-129-3p.

miR-199a-3p targets HMGB1. To explore the underlying targets of miR-199a-3p in Ecto and Endo cells, the targets of miR-129-3p were predicted by the bioinformatics software TargetScan. As shown in Fig. 6A, HMGB1 was found to be one of the targets of miR-129-3p, and a binding site for miR-199a-3p was found on the HMGB1 mRNA 3'UTR. To verify the targeting relationship between miR-129-3p and HMGB1, a luciferase reporter assay was performed. The results showed that luciferase activity was significantly suppressed in Ecto and Endo cells co-transfected with miR-199a-3p mimics and the luciferase reporter vector of wild-type HMGB1 containing the miR-199a-3p binding site sequence, but there was no significant difference in luciferase activity between the negative control- and miR-129-3p mimic-transfected group when the cells were co-transfected with the binding site mutant HMGB1 luciferase reporter vector (Fig. 6B and C). Moreover, Ecto and Endo cells transfected with miR-199a-3p mimics significantly suppressed both the mRNA and protein expression of HMGB1 (Fig. 6D-F). These results suggested 
A

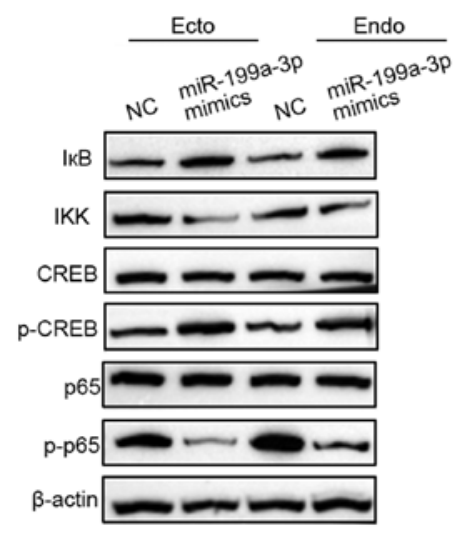

B

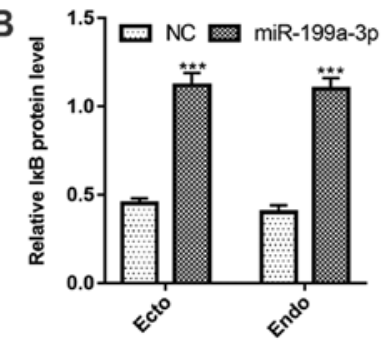

D

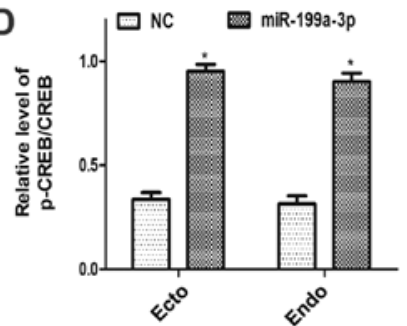

C

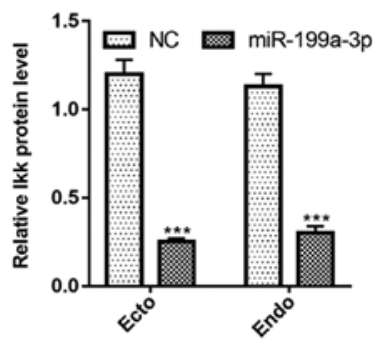

E

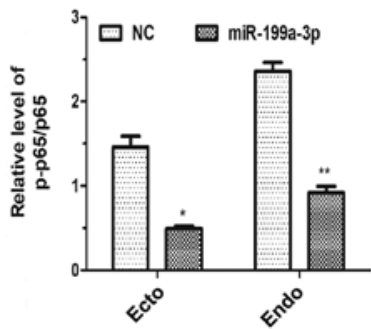

Figure 5. Overexpression of miR-199a-3p suppresses NF-кB signaling in cervical epithelial cells. (A) The protein expression levels of IкB, IKK, p-CREB and p-p65 in Ecto and Endo cells after miR-199a-3p overexpression were analyzed by western blotting. (B-E) The quantification of these western blots. Data represents the mean $\pm \mathrm{SEM} .{ }^{*} \mathrm{P}<0.05,{ }^{* *} \mathrm{P}<0.01,{ }^{* * *} \mathrm{P}<0.001$ vs. NC. miR, microRNA; p-, phosphorylated; Ecto, ectocervical; Endo, endocervical; NC, negative

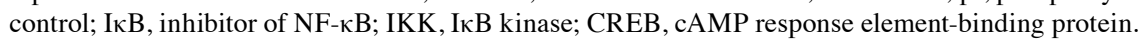

A

HMGB1 wt: 5 ' UUUAGAUGGAAGUUUCUACUGU 3 '

|||||

miR-199a-3p : 3' AUUGGUUACACGUCUGAUGACA 5'

|| || |

HMGB1 mut: 5' UUUAGAUGGAAGUUUCAUGAGU 3'
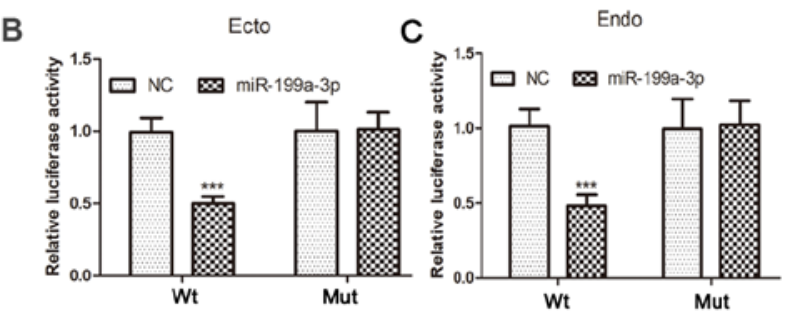
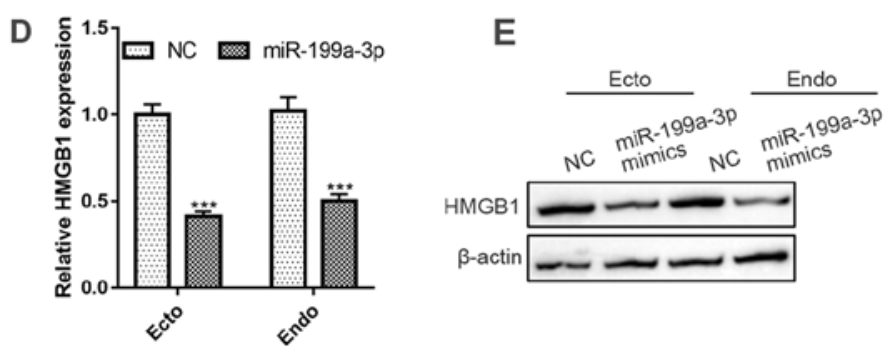

$\mathrm{F}$

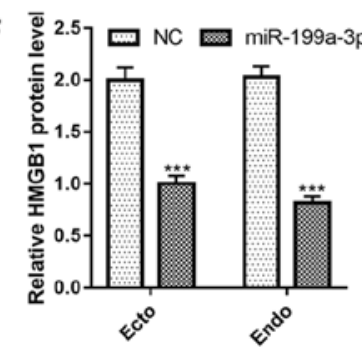

Figure 6. miR-199a-3p targets HMGB1. (A) The predicted binding site between miR-199a-3p and HMGB1. The luciferase activity in (B) Ecto and (C) Endo cells after miR-199a-3p overexpression. (D) The mRNA expression of HMGB1 in Ecto and Endo cells after miR-199a-3p overexpression. (E and F). The protein expression of HMGB1 in Ecto and Endo cells after miR-199a-3p overexpression. Data represents the mean \pm SEM. ${ }^{* * * *} \mathrm{P}<0.001 \mathrm{vs.} \mathrm{NC}$. miR, microRNA; HMGB1, high-mobility group box 1 protein; Ecto, ectocervical; Endo, endocervical; NC, negative control.

that miR-199a-3p could suppress the expression of HMGB1 at both the mRNA and protein levels by directly targeting the 3'UTR of HMGB1 mRNA.

miR-199a-3p regulates inflammation via the $H M G B 1 / T L R 4 / N F-\kappa B$ pathway. To investigate the mechanism by which miR-199a-3p regulates inflammation, adenovirus vectors containing HMGB1 and TLR4 were transfected into both Ecto and Endo cells (the transfection efficiency of pcDNA-HMGB1 and pcDNA-TLR4 in Ecto and Endo cells is presented in Fig. S1B and D), and then the levels of inflammatory cytokines and expression levels of proteins in the NF- $\mathrm{B}$ pathway were analyzed. The results showed that overexpression of HMGB1 and TLR4 significantly reversed the proinflammatory effects of miR-199a-3p in Ecto and Endo cells. The expression levels of TNF- $\alpha$ and IL- $1 \beta$ were upregulated when miR-129-3p was co-transfected with HMGB1 or TLR4 adenovirus vectors compared with those in cells transfected with miR-129-3p mimics alone (Fig. 7A-D). In addition, overexpression of miR-199a-3p significantly suppressed the activation of the proteins in the NF- $\mathrm{B}$ pathway, but this effect was reversed by overexpression of HMGB1 and TLR4. As shown in Fig. 7E-J, overexpression of miR-129-3p upregulated the expression of IKK and $\mathrm{p}-\mathrm{CREB}$, but this effect was reversed by HMGB1 and/or TLR4 overexpression, and the downregulation of $\mathrm{I} \kappa \mathrm{B}$ and p-p65 was also reversed upon co-transfection with HMGB1 and/or TLR4 adenovirus vectors. These results indicated that the inhibition of NF- $\mathrm{BB}$ signaling by miR-129-3p 
A

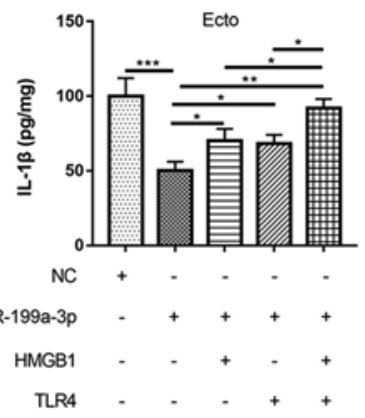

E

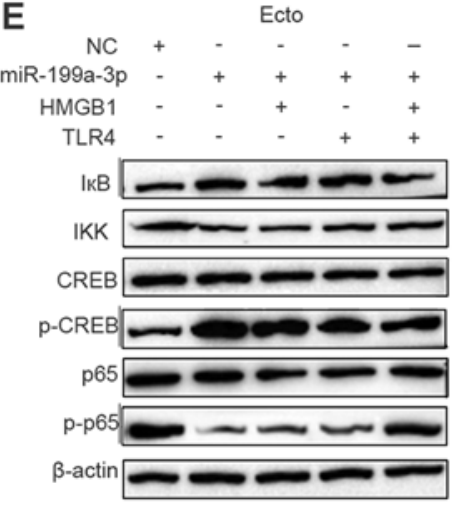

H

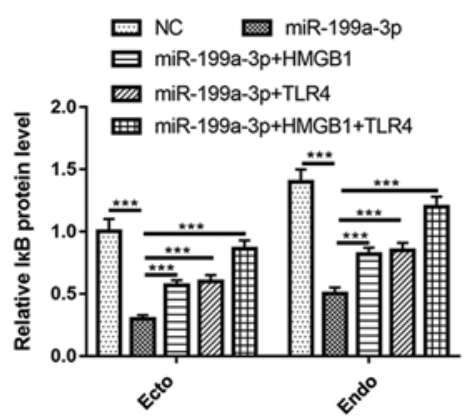

B

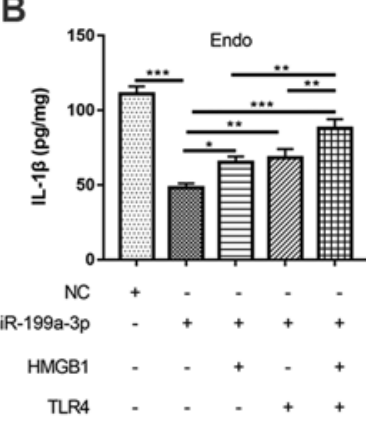

$\mathbf{F}$

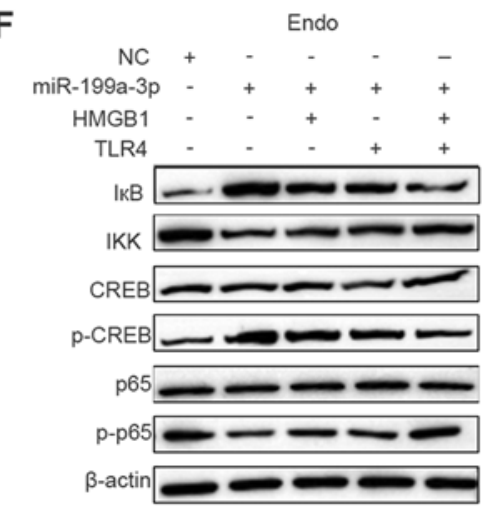

I

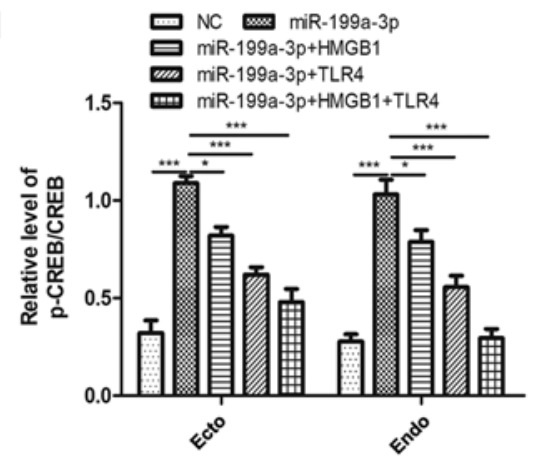

C

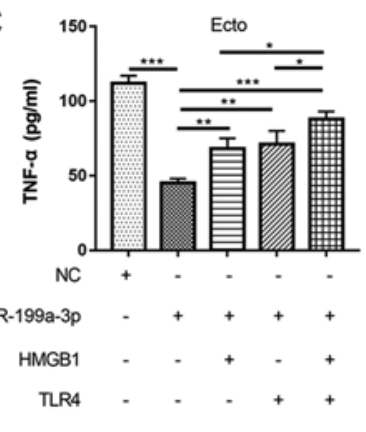

D

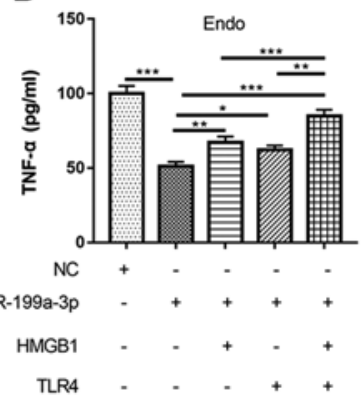

G

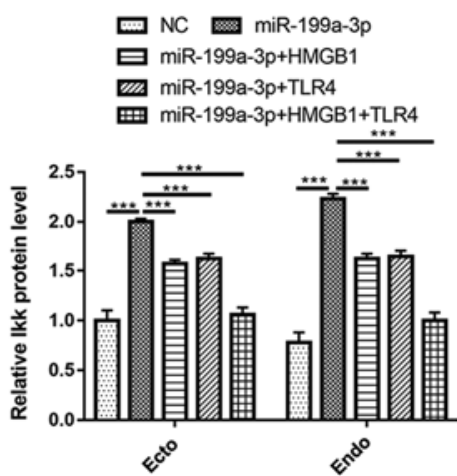

J

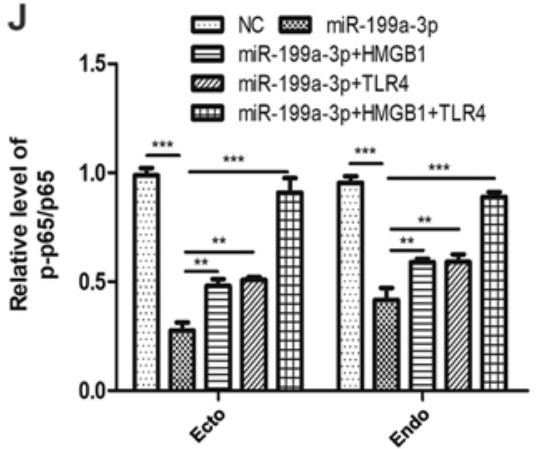

Figure 7. miR-199a-3p regulates inflammation via the HMGB1/TLR4/NF-kB pathway. The Ecto and Endo cells were divided into 5 groups: i) NC group; ii) miR-199a-3p mimics group; iii) miR-199a-3p mimics + pcDNA-HMGB1 group; iv) miR-199a-3p mimics + pcDNA-TLR4 group; v) miR-199a-3p mimics + pcDNA-HMGB1 + pcDNA-TLR4 group. (A-D) The levels of IL-1 $\beta$ and TNF- $\alpha$ in the cell culture medium were measured using an ELISA assay. (E-J) The protein expression levels of I $\mathrm{B}$, IKK, p-CREB and p-p65 in Ecto and Endo cells were determined by western blotting. Data represents the mean \pm SEM. ${ }^{*} \mathrm{P}<0.05,{ }^{* *} \mathrm{P}<0.01,{ }^{* * *} \mathrm{P}<0.001$. miR, microRNA; HMGB1, high-mobility group box 1 protein; Ecto, ectocervical; Endo, endocervical; NC, negative control;

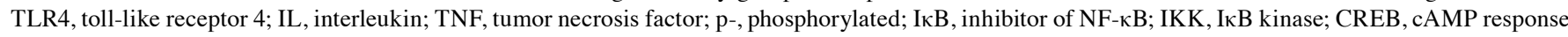
element-binding protein.

occurred through targeting HMGB1 and partly depended on the participation of TLR4. Specifically, miR-129-3p could regulate TLR4/NF- $\kappa \mathrm{B}$ signaling by targeting HMGB1, thus influencing the production of $\mathrm{NF}-\kappa \mathrm{B}$-dependent proinflammatory cytokines.

miR-199a-3p regulates inflammation during $P T B$ in vivo by targeting HMGB1. To determine the role of miR-199a-3p and HMGB1 in inflammation during preterm labor in vivo, miR-199a-3p mimics and/or pcDNA-HMGB1 were transfected into the LPS-induced mouse PTB model (the transfection efficiency of miR-199a-3p mimics and pcDNA-HMGB1 are presented in Fig. S1C and E, respectively). The overexpression of miR-129-3p significantly attenuated the expression of HMGB1 and TLR4 (Fig. 8A-C), and the release of IL-1 $\beta$ and
TNF- $\alpha$ was inhibited in the cervical tissues of LPS-induced PTB mice (Fig. 8D and E). However, the effects of overexpressing miR-129-3p were significantly reversed by the HMGB1 adenovirus vector. After upregulating HMGB1, the expression of TLR4 was also upregulated, and the levels of proinflammatory cytokines IL- $1 \beta$ and TNF- $\alpha$ were concurrently increased in cervical tissues (Fig. 8A-E). Furthermore, $\mathrm{NF}-\kappa \mathrm{B}$ signaling participated in this process. Overexpression of miR-129-3p inhibited the activation of p65, and the level of p-p65 in cervical tissues was decreased compared with that in LPS-induced PTB mice. However, when miR-129-3p mimics and pcDNA-HMGB1 were co-transfected into LPS-induced PTB mice, the expression of p-p65 was upregulated compared with that in the miR-129-3p-overexpression group (Fig. 8A and F). These data showed that miR-129-3p 
A

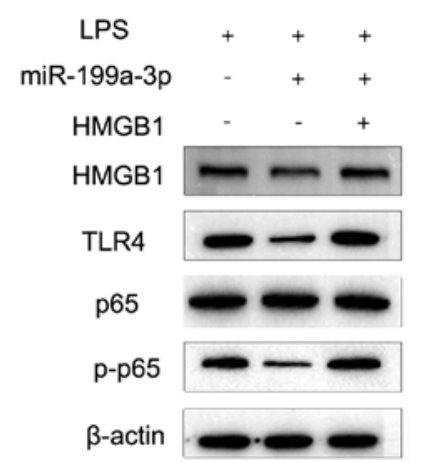

C

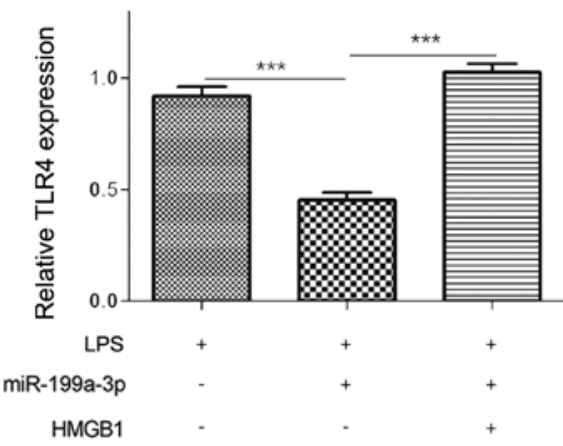

E

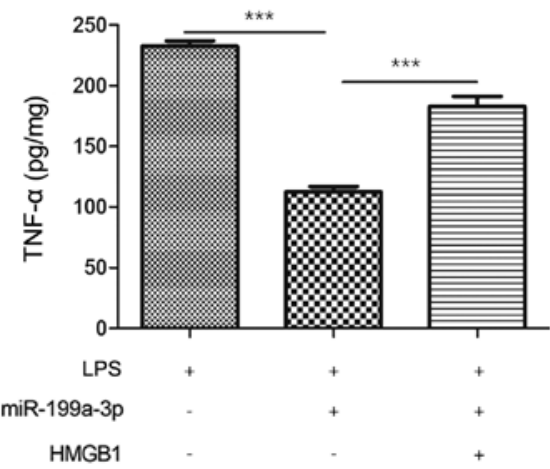

B
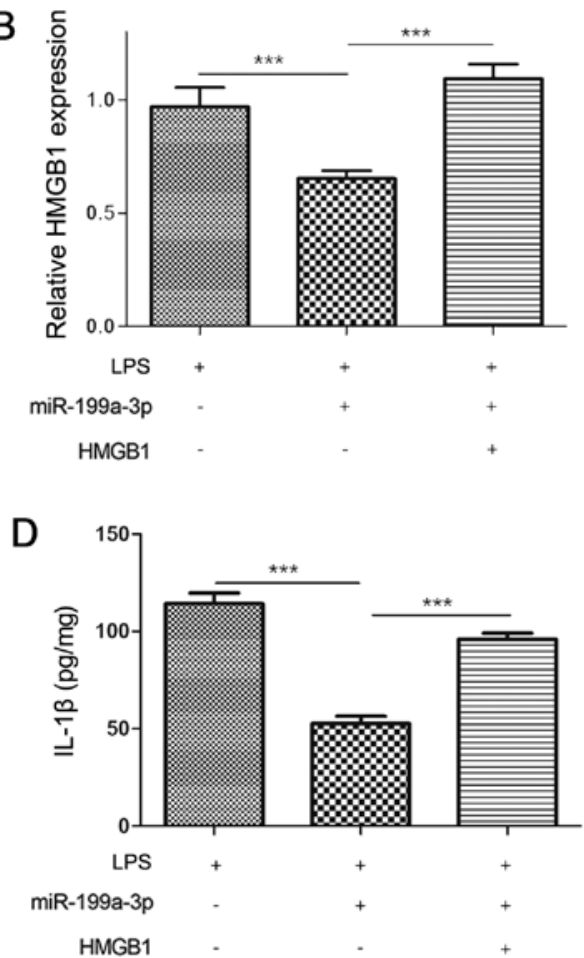

$\mathrm{F}$

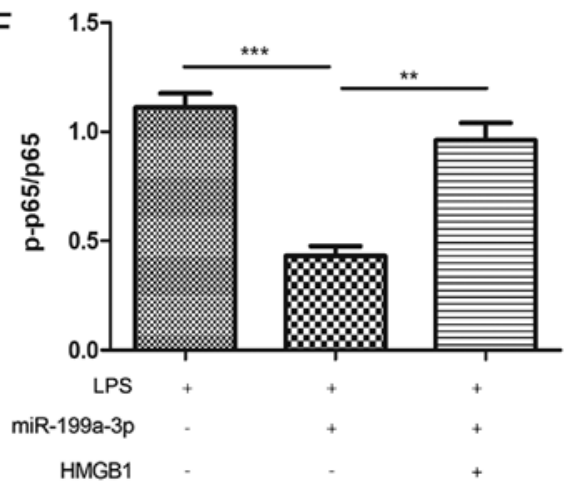

Figure 8. Inflammatory role of miR-199a-3p and HMGB1 during PTB in vivo. The LPS-induced PTB mice were used to determine the protective effect of miR-199a-3p. The miR-199a-3p mimics were transfected into LPS-induced PTB mice with or without co-transfection of pcDNA-HMGB1. (A-C) The protein levels of HMGB1 and TLR4 in cervical epithelial tissues were measured by western blotting. The levels of proinflammatory cytokines (D) IL-1 $\beta$ and (E) TNF- $\alpha$ were measured by ELISA. (A and F) The activation of NF- $\mathrm{\kappa B}$ signaling was determined by the level of p-p65, as measured by western blotting. Data represents the mean \pm SEM. ${ }^{* *} \mathrm{P}<0.01,{ }^{* * *} \mathrm{P}<0.001$. miR, microRNA; HMGB1, high-mobility group box 1 protein; PTB, preterm birth; LPS, lipopolysaccharide; TLR4, toll-like receptor 4; IL, interleukin; TNF, tumor necrosis factor; p-, phosphorylated.

suppressed cervical inflammation in vivo by targeting HMGB1 in order to regulate the TLR4/NF- $\mathrm{B}$ pathway.

\section{Discussion}

The present study explored a novel pathway that regulates the molecular mechanism contributing to cervical inflammation activation, which induces cervical epithelial barrier injury and cervical remodeling. In the present study, the function of miR-199a-3p and its target gene HMGB1 were investigated in inflammatory-related PTB. The results showed that miR-199a-3p was significantly downregulated in patients in the PTB and PPROM groups, as well as in an LPS-induced preterm mouse model and LPS-treated Ecto and Endo cells. In contrast, the expression of HMGB1 and its primary membrane receptor TLR4 were both significantly increased, which was accompanied by the increased release of the proinflammatory factors IL- $1 \beta$ and TNF- $\alpha$. Moreover, the results demonstrated that miR-199a-3p participated in the inflammatory activation of cervical remodeling during pregnancy by inhibiting the activation of the TLR4/NF- $\kappa \mathrm{B}$ proinflammatory signal by targeting the 3'UTR of HMGB1 (Fig. 9).

PTB is defined as delivery before 37 completed weeks of gestation by the World Health Organization and can be subdivided into extremely preterm ( $<28$ weeks), very preterm (28-32 weeks) and moderate to late PTB (32-36 weeks) (31). Currently, PTB is the primary cause of perinatal morbidity and mortality (32), and the second cause of childhood death below the age of 5 years (33). Spontaneous preterm labor is a syndrome caused by multiple pathological processes and causes $70 \%$ of PTBs (34). The increase in uterine contractility, cervical dilatation and rupture of chorioamniotic membranes 


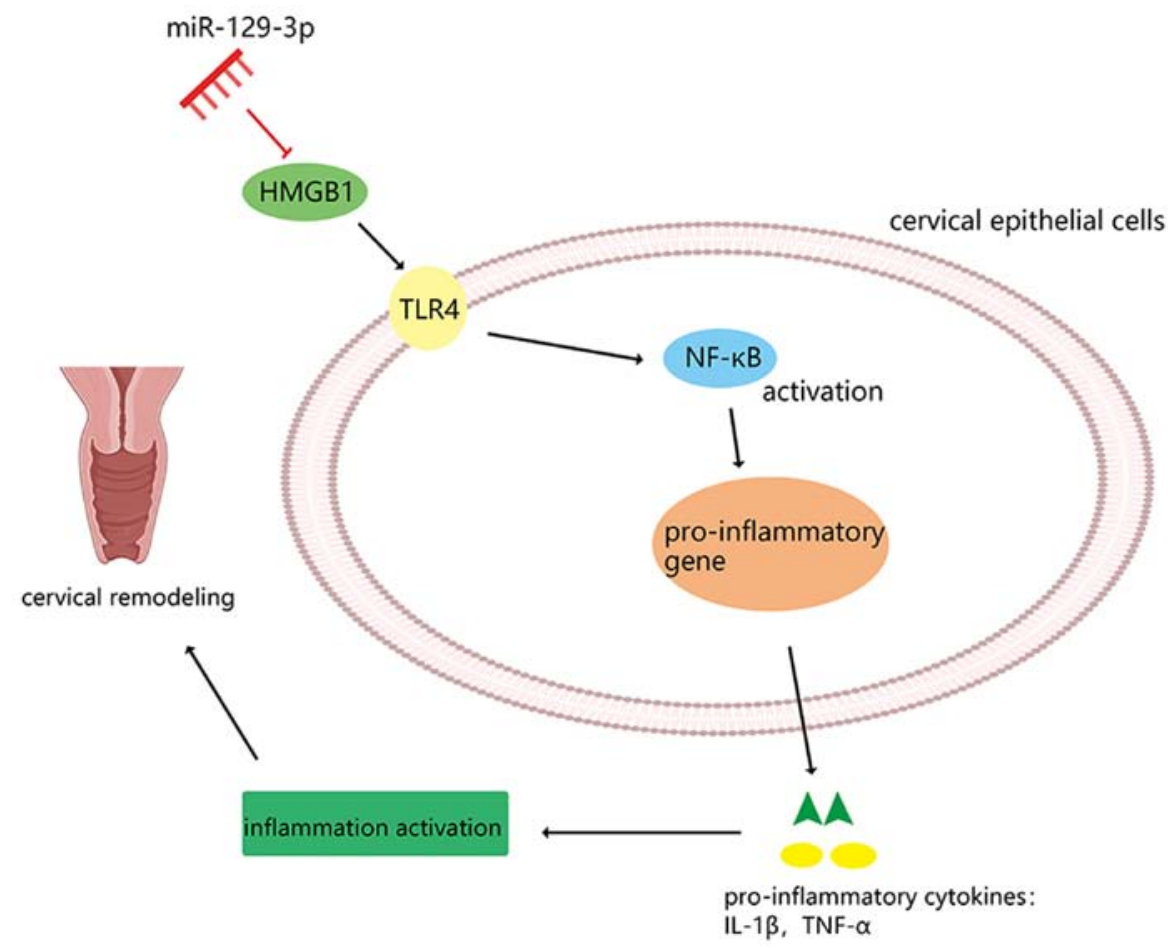

Figure 9. Graphic summary of the findings of the present study. This study suggests that miR-199a-3p plays a negative regulatory role in the cervical epithelial inflammatory process during preterm birth. Furthermore, miR-199a-3p regulates the inflammatory process by targeting HMGB1 to modulate the TLR4/NF- $\mathrm{kB}$ pathway. miR, microRNA; HMGB1, high-mobility group box 1 protein; TLR4, toll-like receptor 4; IL, interleukin; TNF, tumor necrosis factor.

are the 'common pathways' of delivery, both in full term delivery and premature delivery (35). More specifically, the common pathway is activated physiologically in the case of full-term labor, whereas several disease processes activate one or more of the components of the common pathway in the case of preterm labor. Accumulating evidence suggests that preterm labor is a syndrome attributable to multiple pathologic processes (35), including infection (36), vascular disorders (37), decidual senescence, uterine overdistension (38-40), cervical disease (41), breakdown of maternal-fetal tolerance and stress (42). Of these, only intra-amniotic infection/inflammation has been causally linked to spontaneous preterm delivery (43-45). The innate immune system activated by endogenous danger signals causes an inflammatory process in sterile inflammation (46), followed by the release of proinflammatory cytokines, including IL-1 $\beta$, IL-18, IFN- $\gamma$ and TNF- $\alpha(4,47)$. In the present study, it was determined that the levels of IL-1 $\beta$ and TNF- $\alpha$ were significantly increased in PTB, which suggested that the differential regulation of molecules during inflammation in PTB may be novel markers for the diagnosis of PTB.

Stimulating uterine contraction is the first step of preterm delivery, followed by cervical remodeling and early delivery, and studies have shown that premature cervical remodeling may be the main step of spontaneous preterm delivery (48-51). Previous studies have suggested that infection- or inflammatory-mediated destruction of the cervical epithelial barrier promotes cervical remodeling and plays an important role in the pathogenesis of preterm delivery (52-54). However, the pathogenesis of cervical epithelial inflammation needs further study. It is known that miR-199a-3p plays an important role in inflammatory responses (55), and it also plays a negative regulatory role in the NF-KB signaling pathway to modulate inflammatory processes in cystic fibrosis airways (27). Moreover, miR-199a-3p is a crucial regulator of myometrial contractility and prevention of PTB (26). The present study focused on the role of miR-199a-3p in cervical epithelial inflammation. First, it was found that the expression of miR-199a-3p was significantly reduced in the cervical epithelial tissues of patients in the PTB group, in an LPS-induced preterm mouse model and LPS-induced Ecto and Endo cells. Furthermore, overexpression of miR-199a-3p significantly suppressed the expression of HMGB1, TLR4, p-p65, IL-1 $\beta$ and TNF- $\alpha$ in vitro and in vivo. These results indicated that miR-199a-3p plays an important role in the inflammation of cervical epithelial cells during the process of preterm labor and may regulate HMGB1 and TLR4/NF- $\mathrm{KB}$ signaling.

HMGB1 is a highly evolutionarily conserved protein that promotes gene transcription when it is localized to the nucleus and acts as an alarmin when released extracellularly (56). HMGB1 is a late mediator of several inflammatory diseases that signal through several receptors, including advanced glycation end products (RAGE), TLR2 and TLR4 $(57,58)$. Furthermore, HMGB1 binds to receptors that stimulate immune cells to produce various proinflammatory cytokines such as TNF- $\alpha$, IL- $1 \beta$, IL- $1 \alpha$ and IL-8 $(59,60)$. Proinflammatory cytokines can induce excessive cellular or tissue damage to inflammatory lesions $(61,62)$. As the major receptor of endogenous extracellular HMGB1, TLR4 can activate the proinflammatory signaling of the NF- $\mathrm{kB}$ pathway and thus promote the expression of proinflammatory mediators (17-20). Previous reports have revealed that HMGB1 is involved in the occurrence of PTB and plays an important role in the pathogenesis of the inflammatory process in spon- 
taneous PTB (63). The TLR4/NF- $\kappa$ B pathway also plays a critical role in inflammation, and reports have confirmed that the expression and activation of TLR4/NF- $\kappa \mathrm{B}$ signaling are involved in gestational inflammation (64). In the present study, the role of HMGB1, its downstream TLR4/NF- $\kappa$ B signaling in preterm cervical epithelial inflammation and its upstream regulatory mechanism were explored. The results showed that HMGB1 was increased in the cervical epithelial tissues from the patients in the PTB group and the LPS-induced preterm mouse model, and also in LPS-induced Ecto and Endo cells. Notably, the expression of HMGB1 was negatively regulated by miR-199a-3p, which directly targeted the 3'UTR of HMGB1 mRNA. Overexpression of HMGB1 significantly reversed the anti-inflammatory effects of miR-199a-3p mimics in vitro and in vivo. Concurrently, the expression of the TLR4/NF- $\kappa \mathrm{B}$ pathway and proinflammatory cytokines were also upregulated after HMGB1 was overexpressed in LPS-induced preterm labor mice. These results indicated that HMGB1 promotes cervical epithelial inflammation in preterm delivery via the TLR4/NF- $\mathrm{BB}$ pathway, and this molecular axis can be negatively regulated by miR-199a-3p.

Overall, this study suggested that miR-199a-3p plays a negative regulatory role in the cervical epithelial inflammatory process during PTB. Furthermore, miR-199a-3p regulates the inflammatory process by targeting HMGB1 in

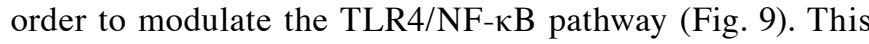
study provides new insights into the mechanism of cervical remodeling in spontaneous preterm delivery and suggests that cervical epithelial inflammation is involved in the occurrence of cervical remodeling to promote the development of preterm labor. In addition, the present study provides a new approach and potential biological target molecules for the prevention of inflammatory-induced spontaneous PTB.

\section{Acknowledgements}

Not applicable.

\section{Funding}

This study was supported by grants from the Yunnan Applied Basic Research Project-Kunming Medical University Union Foundation (grant no. 2017FE468-117); the Health Science and Technology Program of Yunnan Province (grant number 2016NS199); the Science and Technology Talents and Platform Plan of Yunnan Province (grant no. 2017HC008 and S2016IC027).

\section{Availability of data and materials}

The datasets used and/or analyzed during the present study are available from the corresponding author upon reasonable request.

\section{Authors' contributions}

All authors contributed substantially to this manuscript. JP and $\mathrm{JJ}$ contributed equally to this manuscript, they performed all experiments and were the major contributors in writing the manuscript. HW participated primarily in the in vitro tests;
XF contributed primarily to the animal experiments; and XD contributed to conception and design this study and guided the writing of manuscript. All authors read and approved the final manuscript.

\section{Ethics approval and consent for publication}

All human tissues were obtained with the approval of the Hospital Ethical Committee. Informed consent was provided by each participant before surgery. All experimental mouse protocols were approved by the Animal Ethics Committee of the Hospital, and the animals were handled according to the management requirements of the Animal Management Association of the Hospital.

\section{Patient consent for publication}

Not applicable.

\section{Competing interests}

The authors declare that they have no competing interests.

\section{References}

1. McCall EM, Alderdice F, Halliday HL, Vohra S and Johnston L: Interventions to prevent hypothermia at birth in preterm and/or low birth weight infants. Cochrane Database Syst Rev 2: CD004210, 2018.

2. Son M and Miller ES: Predicting preterm birth: Cervical length and fetal fibronectin. Semin Perinatol 41: 445-451, 2017.

3. Gomez-Lopez N, Romero R, Xu Y, Plazyo O, Unkel R, Leng Y, Than NG, Chaiworapongsa T, Panaitescu B, Dong Z, et al: A role for the inflammasome in spontaneous preterm labor with acute histologic chorioamnionitis. Reprod Sci 24: 1382-1401, 2017.

4. Boyle AK, Rinaldi SF, Norman JE and Stock SJ: Preterm birth: Inflammation, fetal injury and treatment strategies. J Reprod Immunol 119: 62-66, 2017.

5. Vink J and Mourad M: The pathophysiology of human premature cervical remodeling resulting in spontaneous preterm birth: Where are we now? Semin Perinatol 41: 427-437, 2017.

6. Carter Moylan HE, Caitlyn Nguyen-Ngo C, Ratana Lim R, and Lappas M: The short chain fatty acids butyrate and propionate protect against inflammation induced activation of mediators involved in active labor: implications for preterm birth. Mol Hum Reprod: April 1, 2020 (Epub ahead of print).

7. Canan Unal C, Esra Karatas E, Fadiloglu E, Portakal O and Beksac MS: Comparison of term and preterm labor procalcitonin and leukocyte cell volume, conductivity and light scatter (VCS) parameters in order to demonstrate the impact of inflammation on the triggering mechanisms of preterm uterin contractions. J Obstet Gynaecol Res 46: 694-698, 2020.

8. Challis JR, Lockwood CJ, Myatt L, Norman JE, Strauss JF III and Petraglia F: Inflammation and pregnancy. Reprod Sci 16: 206-215, 2009.

9. Mendelson CR: Minireview: Fetal-maternal hormonal signaling in pregnancy and labor. Mol Endocrinol 23: 947-954, 2009.

10. Lu HY, Ma JL, Shan JY, Zhang J, Wang QX and Zhang Q: High-mobility group box-1 and receptor for advanced glycation end products in preterm infants with brain injury. World J Pediatr 13: 228-235, 2017.

11. Splichalova A, Slavikova V, Splichalova Z and Splichal I: Preterm life in sterile conditions: A study on preterm, germ-free piglets. Front Immunol 9: 220, 2018.

12. Andersson $\mathrm{U}$ and Tracey KJ: HMGB1 is a therapeutic target for sterile inflammation and infection. Annu Rev Immunol 29: 139-162, 2011.

13. Baumbusch MA, Buhimschi CS, Oliver EA, Zhao G, Thung S, Rood K and Buhimschi IA: High Mobility Group-Box 1 (HMGB1) levels are increased in amniotic fluid of women with intra-amniotic inflammation-determined preterm birth, and the source may be the damaged fetal membranes. Cytokine 81: 82-87, 2016. 
14. Plazyo O, Romero R, Unkel R, Balancio A, Mial TN, Xu Y, Dong Z, Hassan SS and Gomez-Lopez N: HMGB1 induces an inflammatory response in the chorioamniotic membranes that is partially mediated by the inflammasome. Biol Reprod 95: 130, 2016.

15. Menon R, Behnia F, Polettini J, Saade GR, Campisi J and Velarde M: Placental membrane aging and HMGB1 signaling associated with human parturition. Aging (Albany NY) 8: 216-230, 2016.

16. Mukherjee S, Huda S and Sinha Babu SP: Toll-like receptor polymorphism in host immune response to infectious diseases: A review. Scand J Immunol 90: e12771, 2019.

17. Tsung A, Klune JR, Zhang X, Jeyabalan G, Cao Z, Peng X, Stolz DB, Geller DA, Rosengart MR, Billiar TR: HMGB1 release induced by liver ischemia involves Toll-like receptor 4-dependent reactive oxygen species production and calcium-mediated signaling. J Exp Med 204 (12): 2913-2923. 2007.

18. Park JS, Svetkauskaite D, He Q, Kim JY, Strassheim D Ishizaka A and Abraham E: Involvement of toll-like receptors 2 and 4 in cellular activation by high mobility group box 1 protein. J Biol Chem 279: 7370-7377, 2004.

19. Tsung A, Zheng N, Jeyabalan G, Izuishi K, Klune JR, Geller DA Lotze MT, Lu L and Billiar TR: Increasing numbers of hepatic dendritic cells promote HMGB1-mediated ischemia-reperfusion injury. J Leukoc Biol 81: 119-128, 2007

20. Fan J, Li Y, Levy RM, Fan JJ, Hackam DJ, Vodovotz Y, Yang H, Tracey KJ, Billiar TR and Wilson MA: Hemorrhagic shock induces NAD $(\mathrm{P}) \mathrm{H}$ oxidase activation in neutrophils: Role of HMGB1-TLR4 signaling. J Immunol 178: 6573-6580, 2007.

21. Kumar N, Nandula P, Menden H, Jarzembowski J and Sampath V: Placental TLR/NLR expression signatures are altered with gestational age and inflammation. J Matern Fetal Neonatal Med 30 1588-1595, 2017

22. Zhong X, Jiang YZ, Liu P, He W, Xiong Z, Chang W, Zhu J and Cui Q: Toll-like 4 receptor $/ \mathrm{NF \kappa B}$ inflammatory/miR-146a pathway contributes to the ART-correlated preterm birth outcome. Oncotarget 7: 72475-72485, 2016.

23. Elovitz MA, Anton L, Bastek J and Brown AG: Can microRNA profiling in maternal blood identify women at risk for preterm birth? Am J Obstet Gynecol 212: 782.e1-782.e5, 2015.

24. Elovitz MA, Brown AG, Anton L, Gilstrop M, Heiser L and Bastek J: Distinct cervical microRNA profiles are present in women destined to have a preterm birth. Am J Obstet Gynecol 210: 221.e1-11, 2014

25. Wommack JC, Trzeciakowski JP, Miranda RC, Stowe RP and Ruiz RJ: Micro RNA clusters in maternal plasma are associated with preterm birth and infant outcomes. PLoS One 13: e0199029, 2018.

26. Williams KC, Renthal NE, Gerard RD and Mendelson CR: The microRNA (miR)-199a/214 cluster mediates opposing effects of progesterone and estrogen on uterine contractility during pregnancy and labor. Mol Endocrinol 26: 1857-1867, 2012.

27. Bardin P, Marchal-Duval E, Sonneville F, Blouquit-Laye S, Rousselet N, Le Rouzic P, Corvol H and Tabary O: Small RNA and transcriptome sequencing reveal the role of miR-199a-3p in inflammatory processes in cystic fibrosis airways. J Pathol 245: 410-420, 2018.

28. ChenZ,Dong WH,Chen Q,LiQG, QiuZM: NLRP1Downregulation of miR-199a-3p mediated by the CtBP2-HDAC1-FOXP3 transcriptional complex contributes to acute lung injury by targeting. Int J Biol Sci 15: 2627-2640, 2019.

29. Livak KJ and Schmittgen TD: Analysis of relative gene expression data using real-time quantitative PCR and the $2(-\Delta \Delta \mathrm{C}(\mathrm{T}))$ Method. Methods 25: 402-408, 2001

30. Renthal NE, Chen CC, Williams KC, Gerard RD, Prange-Kiel J and Mendelson CR: miR-200 family and targets, ZEB1 and ZEB2, modulate uterine quiescence and contractility during pregnancy and labor. Proc Natl Acad Sci USA 107: 20828-20833, 2010.

31. Organization WH: WHO: Recommended definitions, terminology and format for statistical tables related to the perinatal period and use of a new certificate for cause of perinatal deaths. Modifications recommended by FIGO as amended October 14, 1976. Acta Obstet Gynecol Scand 56: 247-253, 1977.

32. Goldenberg RL, Culhane JF, Iams JD and Romero R: Epidemiology and causes of preterm birth. Lancet 371: 75-84, 2008.

33. Liu L, Johnson HL, Cousens S, Perin J, Scott S, Lawn JE Rudan I, Campbell H, Cibulskis R, Li M, et al; Child Health Epidemiology Reference Group of WHO and UNICEF: Global regional, and national causes of child mortality: An updated systematic analysis for 2010 with time trends since 2000 . Lancet 379: 2151-2161, 2012
34. Paquette AG, Shynlova O, Kibschull M, Price ND and Lye SJ; Global Alliance to Prevent Prematurity and Stillbirth Systems Biology of Preterm Birth Team: Comparative analysis of gene expression in maternal peripheral blood and monocytes during spontaneous preterm labor. Am J Obstet Gynecol 218: 345. e341-345.e330, 2018.

35. Romero R, Espinoza J, Kusanovic JP, Gotsch F, Hassan S, Erez O, Chaiworapongsa T and Mazor M: The preterm parturition syndrome. BJOG 113 (Suppl 3): 17-42, 2006

36. Gonçalves LF, Chaiworapongsa T and Romero R: Intrauterine infection and prematurity. Ment Retard Dev Disabil Res Rev 8: 3-13, 2002.

37. The Preterm Labor Syndrome: Biochemical, Cytologic, Immunologic, Pathologic, Microbiologic, and Clinical Evidence That Preterm Labor Is a Heterogeneous Disease. Am J Obstet Gynecol 168: 288, 1993.

38. Ludmir J, Samuels P, Brooks S and Mennuti MT: Pregnancy outcome of patients with uncorrected uterine anomalies managed in a high-risk obstetric setting. Obstet Gynecol 75: 906-910, 1990

39. Lallar M, Nandal R and Nandal R; Anam U1 Haq: Perinatal outcome in idiopathic polyhydramnios. J Obstet Gynaecol India 65: 310-314, 2015

40. Colditz P: Multiple Pregnancy: Epidemiology, Gestation, and Perinatal Outcome. Twin Res Hum Genet 9: 183-184, 2006.

41. Choi J, Park JW, Kim BJ, Choi YJ, Hwang JH and Lee SM: Funisitis is more common in cervical insufficiency than in preterm labor and preterm premature rupture of membranes. J Perinat Med 44: 523-529, 2016.

42. Hobel CJ: Stress and preterm birth. Clin Obstet Gynecol 47: 856-880, discussion 881-882, 2004.

43. Romero R, Dey SK and Fisher SJ: Preterm labor: One syndrome, many causes. Science 345: 760-765, 2014.

44. Romero R, Gómez R, Chaiworapongsa T, Conoscenti G, Kim JC and Kim YM: The role of infection in preterm labour and delivery. Paediatr Perinat Epidemiol 15 (Suppl 2): 41-56, 2001.

45. Gilman-Sachs A, Dambaeva S, Salazar Garcia MD, Hussein Y, Kwak-Kim J and Beaman K: Inflammation induced preterm labor and birth. J Reprod Immunol 129: 53-58, 2018

46. Chen GY and Nuñez G: Sterile inflammation: Sensing and reacting to damage. Nat Rev Immunol 10: 826-837, 2010.

47. Cappelletti M, Della Bella S, Ferrazzi E, Mavilio D and Divanovic S: Inflammation and preterm birth. J Leukoc Biol 99: 67-78, 2016.

48. Timmons BC, Mitchell SM, Gilpin C and Mahendroo MS: Dynamic changes in the cervical epithelial tight junction complex and differentiation occur during cervical ripening and parturition. Endocrinology 148: 1278-1287, 2007.

49. Gonzalez JM, Xu H, Chai J, Ofori E and Elovitz MA: Preterm and term cervical ripening in CD1 Mice (Mus musculus): Similar or divergent molecular mechanisms? Biol Reprod 81: 1226-1232, 2009.

50. Timmons B, Akins $M$ and Mahendroo M: Cervical remodeling during pregnancy and parturition. Trends Endocrinol Metab 21: 353-361, 2010.

51. Read CP, Word RA, Ruscheinsky MA, Timmons BC and Mahendroo MS: Cervical remodeling during pregnancy and parturition: Molecular characterization of the softening phase in mice. Reproduction 134: 327-340, 2007.

52. Nold C, Anton L, Brown A and Elovitz M: Inflammation promotes a cytokine response and disrupts the cervical epithelial barrier: a possible mechanism of premature cervical remodeling and preterm birth. Am J Obstet Gynecol 206: 208. e1-7, 2012. https://doi.org/10.1016/j.ajog.2011.12.036.

53. Akgul Y, Word RA, Ensign LM, Yamaguchi Y, Lydon J, Hanes J and Mahendroo M: Hyaluronan in cervical epithelia protects against infection-mediated preterm birth. J Clin Invest 124: 5481-5489, 2014

54. Timmons BC and Mahendroo M: Processes regulating cervical ripening differ from cervical dilation and postpartum repair: Insights from gene expression studies. Reprod Sci 14 (Suppl): 53-62, 2007.

55. Gu N, You L, Shi C, Yang L, Pang L, Cui X, Ji C, Zheng W and Guo X: Expression of miR-199a-3p in human adipocytes is regulated by free fatty acids and adipokines. Mol Med Rep 14: 1180-1186, 2016.

56. Lotze MT and Tracey KJ: High-mobility group box 1 protein (HMGB1): Nuclear weapon in the immune arsenal. Nat Rev Immunol 5: 331-342, 2005 . 
57. Bellussi LM, Iosif C, Sarafoleanu C, Jianu E, Duda R, Panaitescu E, Passali FM and Passali D: Are HMGB1 protein expression and secretion markers of upper airways inflammatory diseases? J Biol Regul Homeost Agents 27: 791-804, 2013.

58. Tian J, Avalos AM, Mao SY, Chen B, Senthil K, Wu H, Parroche P, Drabic S, Golenbock D, Sirois C, et al: Toll-like receptor 9-dependent activation by DNA-containing immune complexes is mediated by HMGB1 and RAGE. Nat Immunol 8 : 487-496, 2007.

59. Dong W, Zhu Q, Yang B, Qin Q, Wang Y, Xia X, Zhu X, Liu Z, Song E and Song Y: Polychlorinated biphenyl quinone induces caspase 1-mediated pyroptosis through induction of pro-inflammatory HMGB1-TLR4-NLRP3-GSDMD signal axis. Chem Res Toxicol 32: 1051-1057, 2019.

60. Thankam FG, Roesch ZK, Dilisio MF, Radwan MM, Kovilam A, Gross RM and Agrawal DK: Association of inflammatory responses and ECM disorganization with HMGB1 upregulation and NLRP3 inflammasome activation in the injured rotator cuff tendon. Sci Rep 8: 8918, 2018.
61. Kim EJ, Park SY, Baek SE, Jang MA, Lee WS, Bae SS, Kim K and Kim CD: HMGB1 increases IL-1 $\beta$ production in vascular smooth muscle cells via NLRP3 inflammasome. Front Physiol 9: 313, 2018.

62. Subramanian S, Pallati PK, Sharma P, Agrawal DK and Nandipati KC: Significant association of TREM-1 with HMGB1, TLRs and RAGE in the pathogenesis of insulin resistance in obese diabetic populations. Am J Transl Res 9: 3224-3244, 2017.

63. Son GH, Kim Y, Lee JJ, Lee KY, Ham H, Song JE, Park ST and Kim YH: MicroRNA-548 regulates high mobility group box 1 expression in patients with preterm birth and chorioamnionitis. Sci Rep 9: 19746, 2019.

64. Kumar N, Nandula P, Menden H, Jarzembowski J and Sampath V: Placental TLR/NLR expression signatures are altered with gestational age and inflammation. J Matern Fetal Neonatal Med 30 $1588-1595,2017$.

This work is licensed under a Creative Commons Attribution-NonCommercial-NoDerivatives 4.0 International (CC BY-NC-ND 4.0) License. 